\title{
Study of Temporal Trends of Pollution in the Russian Coastal Areas of the Black Sea by Nuclear and Related Analytical Techniques
}

\author{
Alexander $\mathrm{NK}^{1}$, Olga Bunkova ${ }^{2}$, Frontasyeva MV $^{3 *}$, Pavel Nekhoroshkov ${ }^{3}$, \\ Alexandra Kravtsova ${ }^{3}$, Inga Zinicovscaia ${ }^{3}$ and Nikita Yushin ${ }^{3}$ \\ ${ }^{1}$ Shirshov Institute of Oceanology, Russia \\ ${ }^{2}$ Faculty of Soil Science, Russia \\ ${ }^{3}$ Joint Institute for Nuclear Research, Russia
}

ISSN : 2688-8394

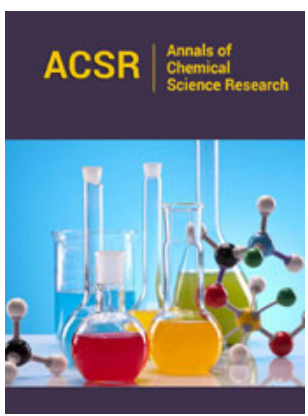

*Corresponding author: Frontasyeva MV, Joint Institute for Nuclear Research, Russia

Submission: 笽 May 13, 2019

Published: 侮 May 21, 2019

Volume 1 - Issue 2

How to cite this article: Alexander N, Olga B, Frontasyeva M, Pavel N, Alexandra K, et al. Study of Temporal Trends of Pollution in the Russian Coastal Areas of the Black Sea by Nuclear and Related Analytical Techniques. Ann Chem Sci Res. 1(2). ACSR.000511.2019.

DOI: 10.31031/ACSR.2019.01.000511

Copyright@ Frontasyeva MV, This article is distributed under the terms of the Creative Commons Attribution 4.0 International License, which permits unrestricted use and redistribution provided that the original author and source are credited.

\begin{abstract}
Ecological state assessments of coastal areas is a worldwide important task in management of the coastal environment. The present study is focused on analysis of key patterns of elemental concentration levels in aquatic organisms/bio-monitors from a model coastal area of the Black Sea at the Taman peninsula. The objects of research were seawater and freshwater, bottom sediments, coastal soils and macrophytes (algae and aquatic plants) of the Krasnodar Region, RF, (Cystoseira barbata, Cystoseira crinita, Cladophora seriace, Ulva rigida, Polysiphonia elongata, Enteromorpha intetinalis, Ceramium rubrum, Padina pavonica, the species of higher hydrophytes: Zoostera noltii, Zoostera marina, Zannichellia palustris, Ruppia cirrhosa, Stuckenia pectinata, Potamogeton pectinatus, Phragmites communis, Carex and Ceratophyllum demersum) which were collected at different distances from the coast. Three complementary analytical techniques: neutron activation analysis (INAA), atomic absorption spectrometry (AAS) and X-ray fluorescence analysis (XRF) were used for determination of concentrations of 10-15 macro and 20-25-trace elements. The study confirmed the uniformity in the character of concentrations/dispersion of elements by bottom sediments in the model zones of the Russian Black Sea coastline, regardless of the increase in distance from the coastline. All bio-monitors showed their own specificity in the accumulation of mineral elements. Similar patterns of concentration and dispersion were found for different morphophysiological parts of macrophytes (root system and supra-bottom green part) of all studied species. Sites of background, polluted and in moderate pollution state among analyzed sites of the Russian coastal zone were proposed. The observed key patterns of elemental accumulation in aquatic plants-bio-monitors, bottom sediments, and soils may be used in the future coastal environmental management and special ecological studies. This study was carried out in collaboration with the Faculty of Biology of Moscow State University and Institute of Oceanography of Russian Academy of Sciences in the framework of the IAEA CRP "Study of Temporal Trends of Pollution in Selected Coastal Areas by the Application of Isotopes and Nuclear Tools" (Contract K41016).
\end{abstract}

Keywords: Bio-monitoring; Pollution; Soil; Bottom sediments; Aquatic vegetation; Taman peninsula; NAA; AAS; XRF

\section{Introduction}

The assessment of the biogeochemical state of the shallow water zone of the seas and the coastal zone is an important fundamental scientific direction. Aquatic ecosystems exist under enhanced anthropogenic pressure, which should be assessed by using modern analytical techniques. At present, one of the essential directions of biogeochemistry is the assessment of the mutual influence of various mineral elements on each other in natural and man-made cycles. Due to the fact that the Black Sea coast is practically the only resort place in Russia, the relevance of ecological and biological monitoring, including the analysis of soil, water, bottom sediments and aquatic organisms in the coastal zone of the sea, become the primary and urgent tasks of Russia and Krasnodar Region. The anthropogenic factor in environmental pollution and the deterioration of the hydro-chemical indicators of the quality of the Black Sea water becomes major topic of environmental analyses; its influence in some cases has disastrous consequences for biota. In addition, the intensification of the technogenic transformation of the Black Sea coastal zone, which has increased in recent years, leads to 
an increase in anthropogenic pressure on the coastal ecosystems in aquatic environment, where macro-phytobenthos performs the most important medium-forming function and is the basis of the food chain.

In the process of the ecological regulation of environmental factors, the biological monitoring of the state of natural systems is the most reasonable, because it is including the analysis of response of a real multi-species community to the entire multi-component load of interacting environmental factors. Algae and sea grasses play an important role in the processes of biological self-purification of polluted waters. In addition, these biological objects are important indicator organisms in conducting of biological monitoring. Therefore, the use of this group of organisms as bio-monitors is not only scientifically grounded, but also a timely decision. An overall objective of the complex study (project) is to analyze the patterns of distribution of fluxes of various types of pollutants in the coastal zone of the Russian part of the Black Sea.

The tasks of the whole project are as follows:

A. The choice of model stations, differing in their geographical, hydrodynamic, physico-chemical and other properties by types of pollution. For these purposes, the following model areas should be selected: a closed bay (Taman Bay), a coastal section with an open water area (Anapa beach), a coastal section with river flow (Sukko Bay), etc. In addition, the stations should have different morphological features of the bottom: silty (muddy), sandy, stony.

B. Selection of the most convenient objects (cosmopolitan aquatic macrophytes) for the purposes of this study.

C. Selection, testing and optimization of field and laboratory methods necessary for the present study.

D. Assessment of oil pollution of water, bottom sediments, soils collected at stations of various types (data are also available).

E. Assessment of changes in the mineral composition of water, bottom sediments, soils and aquatic phototrophs collected at stations of various types.

F. Identification of synergistic and antagonistic effects of the influence of various pollutants on each other.

A wide range of species of algae, animals and microorganisms is used as indicator of the marine environment, which accumulate the elements from it. For the bioindication of heavy metals, macrophytes and mollusks are most commonly used (mollusks are also selected). Macrophytes and mollusks have a special mechanism for the binding of heavy metal ions, which ensures high plasticity and allows them to survive when water is high polluted by trace elements. Most algae accumulate mineral elements in proportion to their content in sea water [1] and in some cases, in bottom sediments [2]. Exceptions are observed only with a high degree of pollution of the habitat $[3,4]$. The spectrum of work related to the accumulation of mineral elements by higher aquatic plants and the use of these organisms as indicators and monitors of the state of the environment is quite wide [5-8]. Given the resistance to pollution of the aquatic environment and the selective ability in the process of absorption of various mineral elements, macrophytes can be used as convenient indicators [9-13].

The problem of global pollution of nature and assessment of the quality of biota includes a wide range of issues of theoretical and applied importance. In the mid-1970s, due to the increased anthropogenic impact on nature, the concept of "monitoring the state of the environment" arose, which included both a theoretical ecological basis and an applied component related to the preservation of the natural environment. The main ideas about this new science in Russia are formulated by Izrael $[14,15]$. The priority in the formulation and justification of the problems of biological monitoring in relation to marine ecosystems was made by Tsyban [16], Patin [17,18], Burdin [19] and Khristoforov [20]. Structurally, the environmental monitoring system includes geophysical, geochemical and biological monitoring [21]. In the framework of this study, we selected several species of marine and freshwater macrophytes as a bio-monitors. The obtained results were concerned with the first model station. The study revealed the key patterns and regularities in the coastal aquatic ecosystem at the Russian coastline of the Black sea.

\section{Research stations}

The works were carried out 2011-2018. The study area is located in the coastal zone of the south-eastern part of the Black Sea within the Krasnodar Region (Figure 1) and includes the Black Sea coast from the Taman Peninsula to the city of Tuapse, the territories of which are distinguished by a large variety of natural conditions. We have chosen four main model and three additional stations, differing in their geographical, hydrodynamic, physicochemical and other properties, in particular, in the types of pollution (Figure 1). The first main model station-Sennoy village at Taman Peninsula, the resort area of which is the great strategic importance, there are international harbors ("Temryuk", "Caucasus", “Taman"). Agricultural activity is actively conducted in the studied area, vineyards are grown, poultry farms are being developed. The connecting role of the Taman Peninsula is reflected in the quality of the environment of the region, for example, in November 2007, a tanker crashed in the Kerch Strait, and in November 2012 near the village of Sennoy accident occurred, as a result of which, 17 carriages with oil derailed. Troitsk Iodine Plant OJSC, the only producer of iodine in Russia and one of the largest in Europe, operates a dozen kilometers from the village. Samples of hydrophytes, bottom sediments, water and coastal soils were collected over a number of years (using frames) at a distance of 20 , 40,60 and 100 meters from the coast in three replications. Station coordinates (N45.27716, E36.96028).

\section{Objects of research}

The objects of research are sea and fresh water, bottom sediments, coastal soils and macrophytes of the Krasnodar Region. It was used following macroalgae (Figure 2): Cystoseira barbata, Cystoseira crinita, Cladophora seriace, Ulva rigida, Polysiphonia 
elongata, Enteromorpha intetinalis, Ceramium rubrum, Padina pavonica, the species of higher hydrophytes - Zoostera noltii, Zoostera marina, Zannichellia palustris, Ruppia cirrhosa, Stuckenia pectinata, Potamogeton pectinatus, Phragmites communis, Carex и Ceratophyllum demersum.

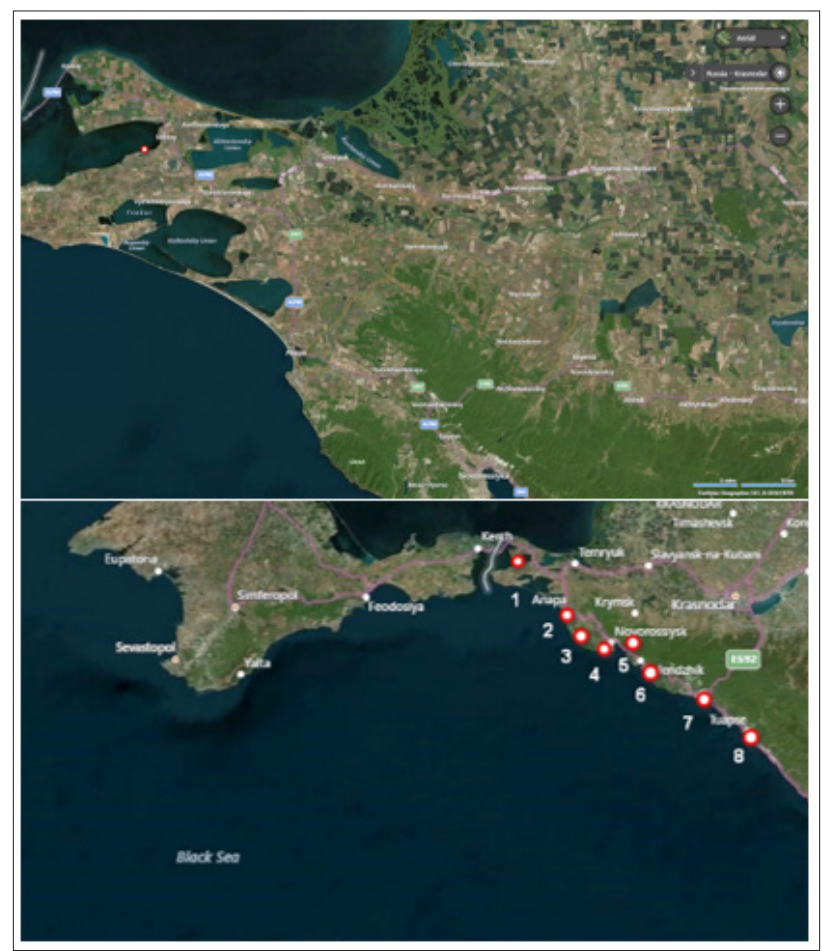

Figure 1: Sampling sites in the north-eastern part of the Black sea region.

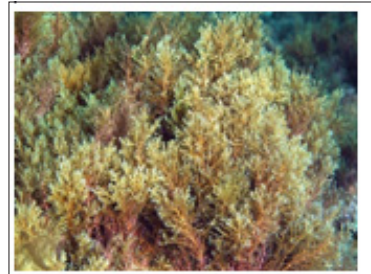

Cystoseira barbata

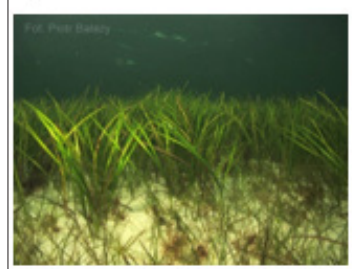

Zannichellia palustris

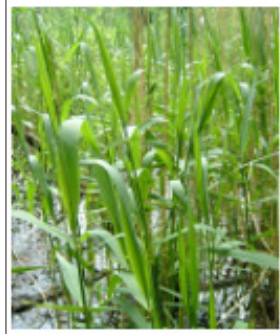

Phragmites communis

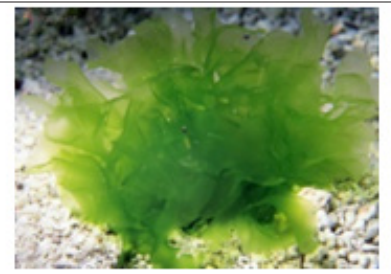

Ulva Rigida

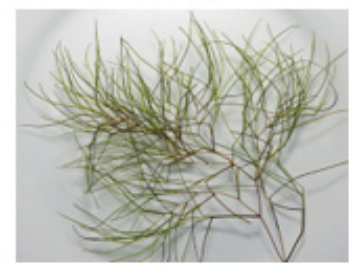

Stuckenia pectinata

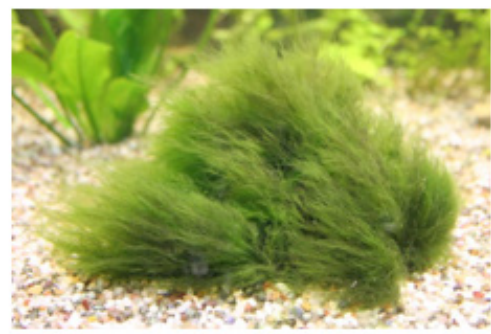

Cladophora seriace

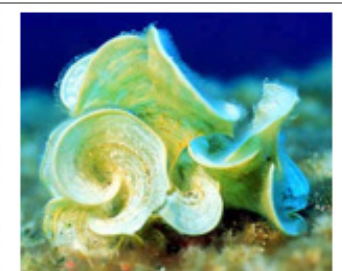

Padina pavonica

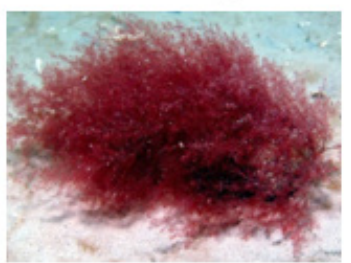

Ceramium rubrum

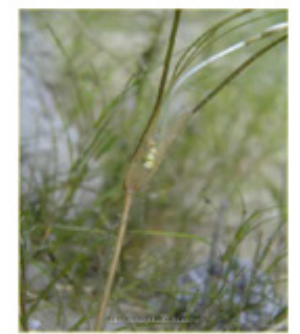

Ruppia cirrhosa

Figure 2: The main species of aquatic bio-monitors in studied area. 


\section{Brief characteristics of macrophyte species}

Cystoseira barbata is a species of perennial brown algae of the Sargasso family. Thallus is a strongly branched bush, standing in water, up to $1 \mathrm{~m}$ high. The central part is thick, about $0.5 \mathrm{~cm}$ in diameter, brown green in color, attached by a sole to underwater rocks. Absorbs the entire surface. The root system is missing. Ulva rigida is a green alga of the ulva family. It grows in the lower littoral of weak places. The plates are rough, harsh to the touch, lanceolate or oval, gradually expanding into wide-round, folded, wide-blade, up to $10 \mathrm{~cm}$ in height, dark green color. Absorbs the entire surface. The root system is missing. Cladophora seriace is a species of green algae of the cladophoric family. Thallus consists of simple or branching green silky threads. Height 1-50 cm. Filamentous algae have a special luscious odor and a sharp, astringent, salty taste. Absorbs the entire surface. The root system is missing.

Zannichellia palustris is a perennial aquatic higher plant of the family of Potamogetonaceae. The stem is very thin, branched, creeping, rooting. Leaves narrowly linear, almost filiform, widened at base in sheath. Absorbs the root system and underwater leaves. Ruppia cirrhosa is a perennial aquatic higher plant of the family of Potamogetonaceae. Stem filiform in nodes rooting. The leaves are almost filiform, thinly pointed, with an expanded sheath. Absorbs the root system and underwater leaves. Stuckenia pectinata is a perennial aquatic higher plant of the Potamogetonaceae. A plant with a long rhizome on which tuber-like thickenings develop in the fall. The ridge comb is not similar to other types of ridges: its stems are very branched, filiform, straight, up to $1.5 \mathrm{~m}$ long; and the leaves are narrow, thin as threads, up to $15 \mathrm{~cm}$ long, dark green or brown. Absorbs the root system and underwater leaves.

Zostera marina $L$ is a large marine higher flowering plant living on sandy and silted grounds. (It has a well-developed root system). Absorbs the root system and underwater leaves. Phragmites communis is a cosmopolitan species, a perennial higher plant of the Poaceae family. It grows in shallow water. Plant height up to 200$300 \mathrm{~cm}$. Leaf blades $0.5-3 \mathrm{~cm}$ wide. Panicle up to $20 \mathrm{~cm}$ long. For the time of research 2011-2018 more than 380 samples were taken, a number of mineral elements were measured in 268 samples. In 2011-2013 measured pH and salinity of water in 2011-2012. measured several ions in water and macrophytes, in 2012-2013. they measured several mineral elements and petroleum products in water, sediments, soils, and macrophytes. Also 2 soil cuts were dug.

\section{Research Methods}

In order to properly assess the biogeochemical situation of the region, we selected (depending on the task) various dominant, but typical representatives of marine macroalgae or the higher plants of the studied area. Typical areas were selected, within which it is quite convenient periodically (in different climatic seasons) to take samples of vegetation, bottom sediments, soils and water. It is known that, depending on the capabilities of the laboratory, various methods for assessing the mineral composition can be used. For these purposes, the method of atomic absorption spectroscopy
(AAS), the method of X-ray fluorescence analysis (XRF) or the method of neutron activation (INAA) is most often used in this study [22]. In this paper, we used all three methods. On the one hand, these methods complemented each other, and on the other, it became possible to compare the results obtained by different methods.

\section{Research Results}

As a result of many years of research conducted on the Black Sea coast from Taman Bay to Tuapse, allowed us to obtain data demonstrating the ecological and species diversity of physiological mechanisms of accumulation of mineral elements from the environment by various macrophytes, which should be taken into account when setting targets using biogeochemical monitoring.

For example, the concentration series of mineral elements according to their average content in the thalli of brown cystosaurine algae can be arranged in a decreasing order: $\mathrm{K}>\mathrm{Ca}>$ $\mathrm{Br}>\mathrm{Na}>\mathrm{Fe}>\mathrm{Mg}>\mathrm{Ba}>\mathrm{As}>\mathrm{Mn}>\mathrm{Zn}>\mathrm{Ni}>\mathrm{Rb}>\mathrm{Cu}>\mathrm{Cr}>\mathrm{Co}>\mathrm{Pb}>$ $\mathrm{U}>\mathrm{Ce}>\mathrm{La}>\mathrm{Se}>\mathrm{Sc}>\mathrm{Cs}>\mathrm{Sb}>\mathrm{Th}>\mathrm{Hg}>\mathrm{Au}$. It is important to note that the content of the same mineral elements in even-aged algae, depending on various factors, can vary from 2 to 99 times or more (depending on the element). The concentration series of mineral elements in the thalli of green algae Cladophora sericea are in the following decreasing order: $\mathrm{Ca}>\mathrm{K}>\mathrm{Cl}>\mathrm{Al}>\mathrm{S}>\mathrm{Fe}>\mathrm{Na}>\mathrm{Mg}>\mathrm{Sr}>\mathrm{Br}>$ $\mathrm{Ti}>\mathrm{Mn}>\mathrm{Ba}>\mathrm{I}>\mathrm{Zn}>\mathrm{V}>\mathrm{As}>\mathrm{Ce}>\mathrm{Rb}>\mathrm{Cr}>\mathrm{Ni}>\mathrm{La}>\mathrm{Co}>\mathrm{Sc}>\mathrm{Th}>\mathrm{Hf}>$ $\mathrm{W}>\mathrm{Mo}>\mathrm{Nb}>\mathrm{Sm}>\mathrm{Cs}>\mathrm{U}>\mathrm{Yb}>\mathrm{Se}>\mathrm{Sb}>\mathrm{Tm}>\mathrm{Gd}>\mathrm{Eu}>\mathrm{Tb} \approx \mathrm{Ta}>\mathrm{Au}$.

In contrast to algae, higher marine hydrophytes have a welldeveloped root system, they are strengthened in soft marine soils and absorb mineral elements due to it, both by the root system from bottom sediments and by the leaves. The concentrations of mineral elements in different parts of Zostera marina are as follows: in living leaves $-\mathrm{Ca}>\mathrm{Mg}>\mathrm{Na}>\mathrm{K}>\mathrm{Fe}>\mathrm{Mn}>\mathrm{Cu}>\mathrm{Zn}>\mathrm{Ni}>\mathrm{Cd}>\mathrm{Pb}$; in dead leaves $-\mathrm{Ca}>\mathrm{Na}>\mathrm{K}>\mathrm{Mg}>\mathrm{Fe}>\mathrm{Mn}>\mathrm{Zn}>\mathrm{Cu}>\mathrm{Ni}>\mathrm{Cd}>\mathrm{Pb}$; in roots $-\mathrm{K}$ $\approx \mathrm{Na}>\mathrm{Ca}>\mathrm{Mg}>\mathrm{Fe}>\mathrm{Mn}>\mathrm{Zn}>\mathrm{Cu}>\mathrm{Ni}>\mathrm{Pb}>\mathrm{Cd}$. In the coastal reedPhragmitesaus tralis (Cav) Trin ExSteud in the following decreasing sequences: in living leaves $-\mathrm{K}>\mathrm{Ca}>\mathrm{S}>\mathrm{P}>\mathrm{Mn}>\mathrm{Fe}>\mathrm{Sr}>\mathrm{Zn}>\mathrm{Cu}>\mathrm{Ni}>$ As $>\mathrm{Pb}>\mathrm{Cd}$; in dead leaves $-\mathrm{K}>\mathrm{Ca}>\mathrm{S}>\mathrm{P}>\mathrm{Fe}>\mathrm{Mn}>\mathrm{Sr}>\mathrm{Zn}>\mathrm{Cu}>\mathrm{Ni}>$ As $>\mathrm{Pb}>\mathrm{Cd}$; in the roots, $\mathrm{Ca}>\mathrm{K}>\mathrm{S}>\mathrm{P}>\mathrm{Fe}>\mathrm{Mn}>\mathrm{Sr}>\mathrm{Zn}>\mathrm{Cd}>\mathrm{Ni}>$ $\mathrm{Cu}>\mathrm{As}>\mathrm{Pb}$.

The shallow water of the Taman Bay can be considered the most convenient platform for complex biogeochemical research. It is known that the chemical composition of bottom sediments is determined by the many factors, one of which is the composition of the external material being brought. Further transformation of bottom sediments in the process of diagenesis is largely determined by the biogenic component the nature of underwater vegetation. Figure 3 demonstrates the average range of concentrations of a number of mineral elements in bottom sediments located 100 meters inland from the coastline.

Analysis of the correlation dependences of the concentrations of mineral elements in bottom sediments showed strong positive correlations for a number of elements. It is interesting to note that this method made it possible to clearly demonstrate the degree 
of associative stability of groups of chemical elements, which, for example, acting with coastal drains, settle in the coastal zone: Fe-S (0.91), Fe-Mn (0.91), Mn-S (0.87) , Ca-S (0.84), Fe-Ca (0.82), or accumulate at the far distance from the coast in the bottom sediments as a result of biogenic processes: Sr-As (0.93), Sr-P (0.79). It is known that the main direction of biogeochemistry is the concept of biogeochemical provinces, which is based on determining the specificity of the behavior of mineral elements within a certain territory. The general content and specificity of the behavior of these elements can be associated both with their excess and deficiency in the environment. The most important technique in biogeochemistry is to determine the ratio of the content of the element under study to a certain standard, and one of the integrative analytical approaches is to build geochemical spectra (Figure 4).

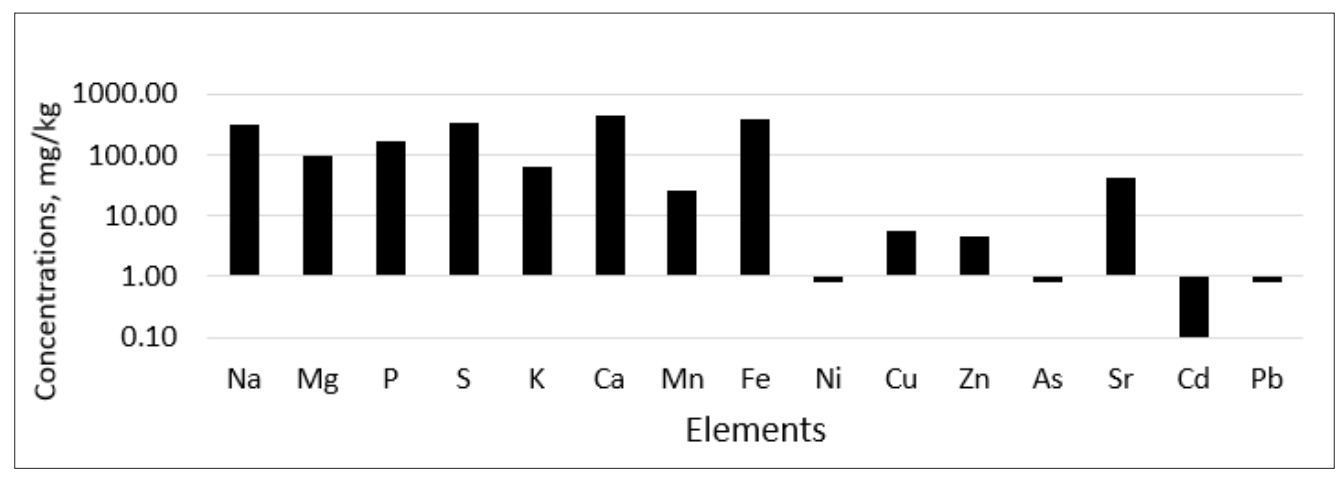

Figure 3: Average concentrations of several macro and microelements in bottom sediments in $100 \mathrm{~m}$ zone from the coast (logarithmic scale).

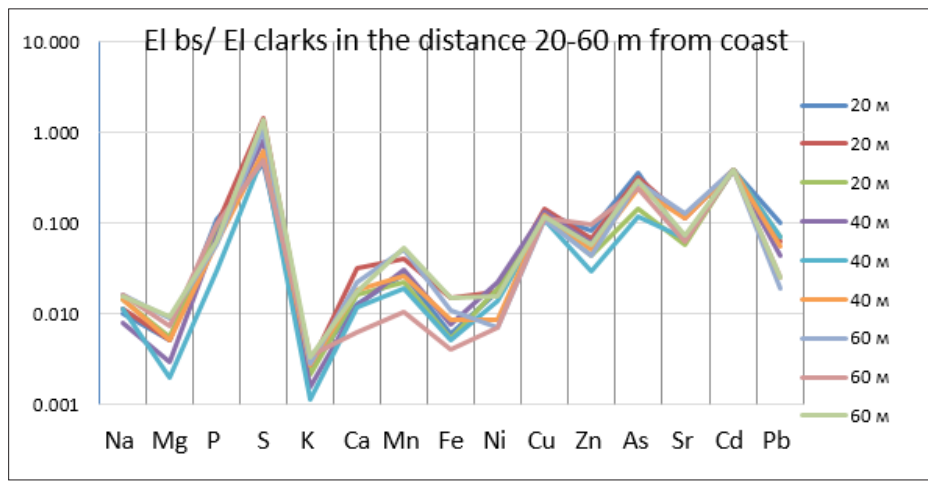

Figure 4: Coefficients of concentrations (El bs/El clarks) in the bottom sediments at the different distance from the coast.

When constructing the spectra data, chemical elements are sequentially placed on the abscissa axis according to their ordinal number, and the ratio of the content of each element (in the each sample) to the average content in the lithosphere or earth crust ("Clarke"-percentage abundance or bulk earth values) is deposited on the ordinate axis. Values higher than one indicate the concentration of an element in a given province (territory), and less indicate dispersion of element. In our studies, to calculate the concentration coefficient, the bulk earth values of the elements, established by Vinogradov [23]. The constructed biogeochemical spectra allowed us to make several important conclusions. First, there is a uniformity in the character of concentration/dispersion of elements by bottom sediments, regardless of the increase in distance from the coastline. Secondly, characteristic of almost all elements is their dispersion from bottom sediments into the surrounding marine environment. To understand the degree of concentration/dispersion, the values of the coefficients are set next to each element: $\mathrm{Na} 0.0, \mathrm{Mg} \mathrm{0.0,} \mathrm{P} \mathrm{0.2,} \mathrm{S} \mathrm{0.7,} \mathrm{K} \mathrm{0.0,} \mathrm{Ca} \mathrm{0.0,} \mathrm{Mn} \mathrm{0.0,}$ Fe 0.0, Ni 0.0, Cu 0.1, Zn 0.1, As 0.5, Sr 0.1, Cd 0.4, Pb 0.0. From the data obtained it is clear that the highest values of the coefficients are characteristic of $\mathrm{S}$, As and $\mathrm{Cd}$. Lower values are for $\mathrm{P}, \mathrm{Cu}$ and Sr. The coefficients characteristic of the remaining elements is less than one hundredth. Thus, the data obtained suggest that the greatest dispersion in the aquatic environment is characteristic of lithophilic and siderophilic elements, and the concentration (or its tendency) is typical of chalcophilic elements $(\mathrm{S}, \mathrm{As}, \mathrm{Cd}, \mathrm{Cu})$.

Correlation analysis showed that all plants have their own specificity in the accumulation of mineral elements, i.e. each plant exists in its own ecological niche. For example, analysis of the correlation coefficients of the concentration of elements in the Zannichellia palustris ash showed high positive correlations for Ca$\mathrm{Mg}$ (0.95), Pb-Cu (0.93), Pb-Zn (0.91), Cu-Zn (0.88) and negative for $\mathrm{P}-\mathrm{Na}(-0.82)$. It is interesting to emphasize that a number of pairs with the high correlation dependencies, such as Ca-S (0.88), Fe-Mn (0.71)), Sr-As (0.80), Sr-P (0.81) correspond to pairs of elements with high linear dependencies in the bottom sediments. Analysis of elements in Ruppia cirrhosa ash showed high positive correlations 
for As-S (0.98), SP (0.84), As-P (0.79), Cd-Zn (0.85), Pb-Cd (0.79), and also $\mathrm{Pb}-\mathrm{Cu}$ (0.94), $\mathrm{Pb}-\mathrm{Zn}(0.94), \mathrm{Cu}-\mathrm{Zn}(0.85)$. Analysis of the Stuckenia pectinata ash showed strong positive correlations for SK (0.94), Ca-K (0.90), As-P (0.89), Sr-S (0.88), KP (0.86), Fe-Mg (0.83), K-S (0.77), As-K (0.77), K-Na (0.74), and also Ca-Mg (0.89). It is interesting to note that the high correlation dependence characteristic of all the plant species we studied was found only for the $\mathrm{Zn}-\mathrm{Cu}$ pair (0.87). Taking the plant ash as a kind of biosubstance capable of accumulating and returning a certain number of chemical elements to the environment, we were determined their accumulation factors (concentration and dispersion) relative to the bulk earth values earth's crust as in the case of bottom sediments.

As a result of this analysis, it was shown that all the mineral elements accumulated in the ashes can be divided into two groups (Table 1). Regardless of the species and part of the plant, the first group includes five mineral elements $\mathrm{P}, \mathrm{Fe}, \mathrm{Ni}, \mathrm{Zn}$ and $\mathrm{Pb}$, the coefficients of which are less than one. In some cases, this group includes $\mathrm{Mg}$ and $\mathrm{Cu}$. The second group includes $\mathrm{K}, \mathrm{Na}, \mathrm{Ca}, \mathrm{Mn}, \mathrm{Sr}, \mathrm{S}$, $\mathrm{Cd}$, As, as well as in most cases $\mathrm{Mg}$ and sometimes $\mathrm{Cu}$. The second group is characterized by the factor greater than one. It is interesting to note that $\mathrm{S}$ is characterized by the highest concentration.

Table 1: The accumulation factors (concentration/dispersion) of elements in sea grasses, calculated on the ash.

\begin{tabular}{|c|c|c|c|}
\hline \multicolumn{2}{|l|}{ Subject <1 } & \multicolumn{2}{|c|}{ Elements with accumulation factors (concentration / dispersion) } \\
\hline & & $\geq 1$ & \\
\hline \multirow{2}{*}{ Zannichellia palustris $L$. } & Top part & $\mathrm{Pb}_{0.0}, \mathrm{Fe}_{0.1}, \mathrm{Ni}_{0.3}, \mathrm{Zn}_{0.4}, \mathrm{Cu}_{0.5}, \mathrm{P}_{0.5}, \mathrm{Mg}_{0.8}$ & $\mathrm{Ca}_{4.0^{\prime}}, \mathrm{Mn}_{4.1}, \mathrm{Sr}_{4.2}, \mathrm{Cd}_{4.3,}, \mathrm{~K}_{5.9}, \mathrm{As}_{6.0^{\prime}}, \mathrm{Na}_{6.6^{\prime}} \mathrm{S}_{47.2}$ \\
\hline & Root system & $\mathrm{Pb}_{0.0}, \mathrm{Fe}_{0.1}, \mathrm{Ni}_{0.3}, \mathrm{P}_{0.5}, \mathrm{Zn}_{0.6}$ & $\begin{array}{c}\mathrm{Cu}_{1.1,} \mathrm{Mg}_{1.5^{\prime}}, \mathrm{Mn}_{3.1,}, \mathrm{Cd}_{3.8,} \mathrm{Sr}_{4.6^{\prime}} \mathrm{As}_{6.2} \\
\mathrm{Na}_{7.7}, \mathrm{~K}_{10.0^{\prime}} \mathrm{Ca}_{10.2}, \mathrm{~S}_{61.9}\end{array}$ \\
\hline \multirow{2}{*}{ Ruppia cirrhosa (Petagna) Grande } & Top part & $\mathrm{Fe}_{0.0}, \mathrm{~Pb}_{0.1}, \mathrm{Ni}_{0.2}, \mathrm{P}_{0.5}, \mathrm{Zn}_{0.7}, \mathrm{Cu}_{0.9}$ & $\mathrm{Mg}_{1.22^{\prime}} \mathrm{Mn}_{4.0^{\prime}}, \mathrm{Ca}_{5.5,}, \mathrm{As}_{5.6^{\prime}}, \mathrm{Na}_{5.9}, \mathrm{~K}_{6.1}, \mathrm{Cd}_{7.5}, \mathrm{Sr}_{14.2^{\prime}}, \mathrm{S}_{35.5}$ \\
\hline & Root system & $\mathrm{Pb}_{0.1}, \mathrm{Fe}_{0.1}, \mathrm{Ni}_{0.3}, \mathrm{P}_{0.6}, \mathrm{Zn}_{0.8}$ & $\mathrm{Cu}_{1.3^{\prime}}, \mathrm{Mg}_{1.77^{\prime}}, \mathrm{Mn}_{2.2^{\prime}}, \mathrm{K}_{4.8^{\prime}} \mathrm{S}_{\mathrm{S}_{48.1}}^{\mathrm{Ca}_{5.1}}, \mathrm{Cd}_{6.6,} \mathrm{Na}_{8.8^{\prime}} \mathrm{As}_{8.9,} \mathrm{Sr}_{11.8^{\prime}}$ \\
\hline \multirow[t]{2}{*}{ Stuckenia pectinata $L$. } & Top part & $\mathrm{Pb}_{0.0,}, \mathrm{Fe}_{0.1}, \mathrm{P}_{0.4^{\prime}}, \mathrm{Ni}_{0.5^{2}}, \mathrm{Zn}_{0.5^{\prime}}, \mathrm{Cu}_{0.7}$ & $\mathrm{Mg}_{1.77^{\prime}}, \mathrm{K}_{4.4}, \mathrm{As}_{4.5,}, \mathrm{Mn}_{5.1}, \mathrm{Ca}_{6.1}, \mathrm{Cd}_{6.2,} \mathrm{Na}_{6.5}, \mathrm{Sr}_{7.2^{\prime}}, \mathrm{S}_{42.0}$ \\
\hline & Root system & $\mathrm{Fe}_{0.0^{\prime}} \mathrm{Pb}_{0.3,}, \mathrm{P}_{0.4^{\prime}} \mathrm{Ni}_{0.4}, \mathrm{Zn}_{0.7}$ & $\mathrm{Mg}_{1.4^{\prime}} \mathrm{Mn}_{1.77^{\prime}}, \mathrm{K}_{4.0^{\prime}} \mathrm{Ca}_{4.5^{\prime}}, \mathrm{As}_{5.2,}, \mathrm{Na}_{5.9^{\prime}} \mathrm{Sr}_{7.3^{\prime}} \mathrm{Cd}_{10.4}, \mathrm{~S}_{46.6}$ \\
\hline \multirow[t]{2}{*}{ Potamogeton compressus $L$. } & Top part & $\mathrm{Pb}_{0.0}, \mathrm{Fe}_{0.1}, \mathrm{P}_{0.3}, \mathrm{Ni}_{0.3}, \mathrm{Zn}_{0.3}, \mathrm{Cu}_{0.5}$ & $\mathrm{Mg}_{1.9}, \mathrm{Cd}_{2.8,} \mathrm{Mn}_{4.0}, \mathrm{Sr}_{4.1}, \mathrm{~K}_{4.3}, \mathrm{As}_{4.3,}, \mathrm{Ca}_{4.7}, \mathrm{Na}_{6.7}, \mathrm{~S}_{49.8}$ \\
\hline & Root system & $\mathrm{Fe}_{0.1}, \mathrm{P}_{0.2}, \mathrm{Ni}_{0.3}, \mathrm{Zn}_{0.5}, \mathrm{~Pb}_{0.6}, \mathrm{Mg}_{0.8}$ & $\mathrm{Mn}_{1.0,} \mathrm{Cu}_{1.2}, \mathrm{~K}_{3.1}, \mathrm{Ca}_{3.1}, \mathrm{Sr}_{3.3}, \mathrm{As}_{3.8} \mathrm{Na}_{5.4}, \mathrm{Cd}_{18.3}, \mathrm{~S}_{38.6}$ \\
\hline
\end{tabular}

The data obtained allow us to draw several conclusions:

First, as a result of biological concentration processes (with the participation of the entire plant surface), higher marine hydrophytes are able to accumulate from the environment not only the necessary macro and microelements, but a large number of other elements, for example, $\mathrm{Sr}, \mathrm{Cd}, \mathrm{As}, \mathrm{Ni}, \mathrm{Pb}$..(Figure 5-8). It is likely that in addition to participation in physiological processes, many elements can simply be deposited both in the cell and the apoplast, and then pass into the environment, but in a different non-toxic form and form bottom sediments. It is possible that such a process is a global evolutionarily finely tuned global mechanism for detoxification and self-purification of the aquatic environment.

Secondly, the same type of concentration and dispersion was found for different morphophysiological parts of macrophytes (root system and supra-bottom green part) of all studied species (particularly in Figure 5-8). This confirms the unified evolutionary character of the mechanisms of concentration and dispersion.

Thirdly, the high values of accumulation factors (concentration factors) $\mathrm{S}$ in hydrophyte ash can be, on the one hand, the result of coastal runoff from agricultural land (long-term treatment of vineyards with copper sulphate), on the other hand, the environmental features of the Black Sea.

When comparing the values showing the degree of accumulation of chemical elements in living and already dead green above-bottom parts of Zannichellia palustris L (Figure 5), it is clear that they are almost the same. This statement again shows that, in addition to their production function, aquatic macrophytes perform an equally important ecological, evolutionary streamlined function of organisms-sorbents capable of purifying the aquatic environment.

Thus, the data obtained by us really allow us to assume that the shallow-water part of the Taman Bay in the area of the village of Sennoy as a conditionally pristine background area. It is shown that in this area a certain part of $\mathrm{Ca}, \mathrm{S}, \mathrm{Fe}$ and $\mathrm{Pb}$ enters the sea with coastal runoff, but in the coastal zone some of these elements settle and accumulate in bottom sediments, which does not contradict the classical concept of sedimentation. The increase with the removal of the $\mathrm{Sr}$, As and $\mathrm{P}$ content from the coastline suggests that their accumulation in the bottom sediments may be associated with biogenic processes. The uniformity of concentration and 
dispersion of elements by bottom sediments, regardless of their distance from the coast, can probably serve as an example of the general evolutionarily well-established geochemical principle of concentration and dispersion of chemical elements in the marine environment. The group of lithophilic and siderophilic elements is characterized by the highest dispersion and chalcophilic elements ( $\mathrm{S}, \mathrm{As}, \mathrm{Cd}, \mathrm{Cu}$ ) by concentration (or its tendency). The ash content in all plants ranges from 20 to $30 \%$ of the dry residue.

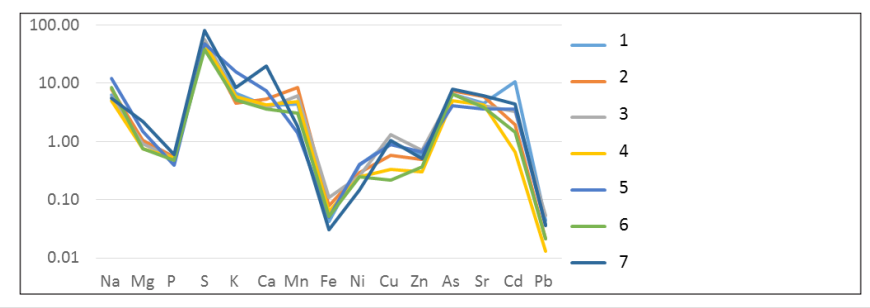

Figure 5: Coefficient of accumulation of elements in ash of Zannichellia palustris L: 1.20m from coast, top part; $2.20 \mathrm{~m}$ from coast, dead top part; $3.20 \mathrm{~m}$ from coast, bottom part (roots); $4.40 \mathrm{~m}$ from coast, top part; $5.40 \mathrm{~m}$ from coast, bottom part (roots); 6.60m from coast, top part; $7.60 \mathrm{~m}$ from coast, bottom part (roots).

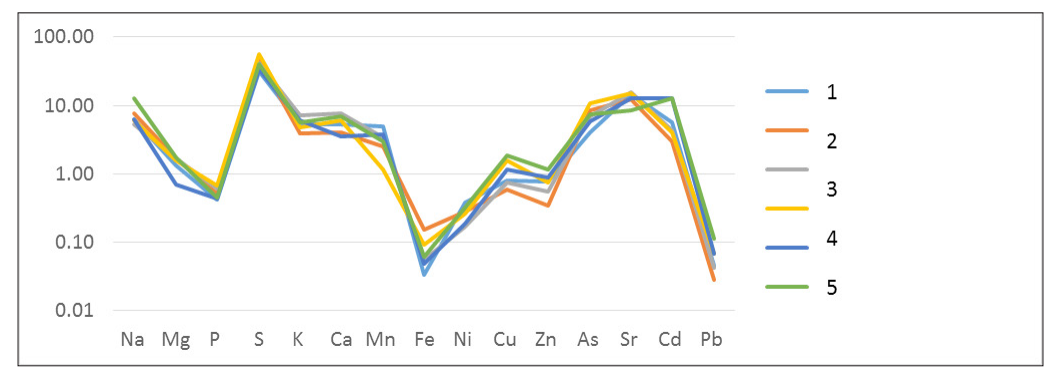

Figure 6: Coefficient of accumulation of elements in ash of Ruppia cirrhosa (Petagna) Grande: $1.20 \mathrm{~m}$ from coast, top part; $2.20 \mathrm{~m}$ from coast, bottom part (roots); $3.40 \mathrm{~m}$ from coast, top part; $4.40 \mathrm{~m}$ from coast, bottom part (roots); $5.60 \mathrm{~m}$ from coast, bottom part (roots).

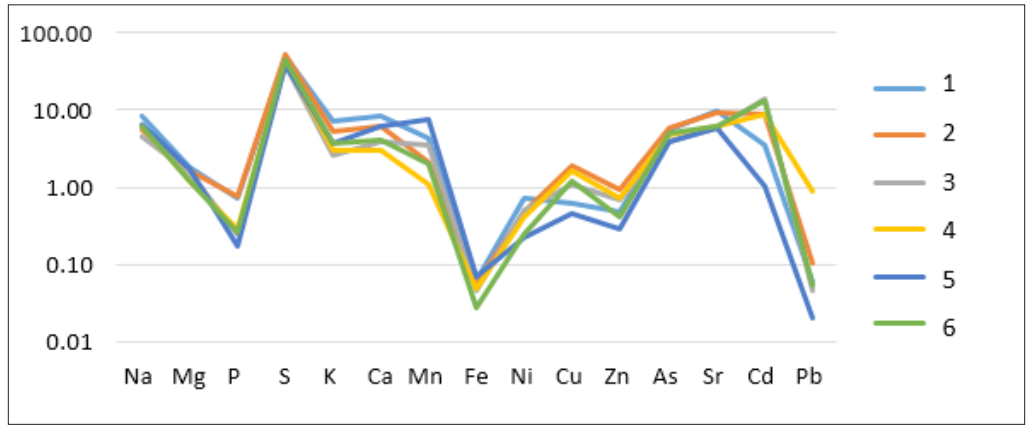

Figure 7: Coefficient of accumulation of elements in ash of Stuckenia pectinata L: 1.20m from coast, top part; $2.20 \mathrm{~m}$ from coast, bottom part (roots); $3.40 \mathrm{~m}$ from coast, top part; $4.40 \mathrm{~m}$ from coast, bottom part (roots); $5.60 \mathrm{~m}$ from coast, top part; $6.60 \mathrm{~m}$ from coast, bottom part (roots).

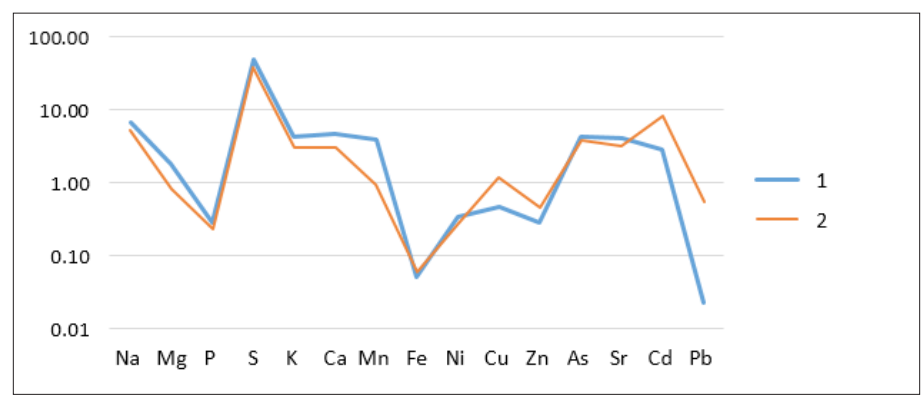

Figure 8: Coefficient of accumulation of elements in ash of Potamogeton compressus L: 1.20m from coast, top part; $2.20 \mathrm{~m}$ from coast, bottom part (roots).. 
Studies have shown a clear species difference in the content of the total content in particular macro-elements. The maximum number of which is typical for Zannichellia palustris $L$ (Figure 5) and the minimum for Potamogeton compressus L (Figure 8). All mineral elements accumulated in the ashes of marine plants can be divided into two groups. It is important to emphasize that, regardless of the species and part of the plant, the first group includes five mineral elements $\mathrm{P}, \mathrm{Fe}, \mathrm{Ni}, \mathrm{Zn}$ and $\mathrm{Pb}$, whose coefficients are less than one. The second group includes $\mathrm{K}, \mathrm{Na}, \mathrm{Ca}, \mathrm{Mn}, \mathrm{Sr}, \mathrm{S}, \mathrm{Cd}$, As, as well as, in the most cases, Mg. The second group is characterized by a factor higher than one. It is interesting to note that $\mathrm{S}$. is characterized by the highest concentration.

Correlation analysis showed that all plants have their own specificity in the accumulation of mineral elements, that is, each plant exists in its own ecological niche. Studies showed that higher marine hydrophytes accumulate from the environment not only the necessary macro and trace elements, but a large number of other elements, for example-Sr, $\mathrm{Cd}, \mathrm{As}, \mathrm{Ni}, \mathrm{Pb}$. Concentrations of some of these elements can significantly exceed the abundances in earth's crust. It is likely that in addition to participation in physiological processes, many elements can simply be deposited both in the cell and the apoplast, and then pass into the environment, but in a different non-toxic form [24] and form bottom sediments. It is possible that such a process is a global evolutionary streamlined global mechanism for detoxification and self-purification of the aquatic environment. For different morphophysiological parts of macrophytes (root system and supra-green part) of all species studied by us, the same type of concentration and dispersion is found. It also confirms the evolutionary nature of the mechanisms of concentration and dispersion. The high values of the concentration coefficients $\mathrm{S}$ in the hydrophyte ash can be, on the one hand, the result of coastal runoff from agricultural land (perennial cultivation of vineyards with copper sulphate), on the other, the ecological features of the Black Sea.

Thus, in addition to their production function, aquatic macrophytes perform an equally important ecological, evolutionary streamlined function of organisms-sorbents capable of purifying the aquatic environment. In conclusion, we would like to emphasize that our proposed approach using geochemical spectra to describe the accumulative processes of chemical elements relative to abundances in earth's crust in plant ashes, allowed us to identify groups of elements that differ in the level of accumulation for the first time. Therefore, this approach can be used for biomonitoring of the environment.

\section{Conclusion}

a. Higher marine hydrophytes are able to accumulate from the environment not only the necessary macro and microelements; the same type of concentration and dispersion was found for different morphophysiological parts of macrophytes (root system and supra-bottom green part) of all studied species.

b. Shallow-water part of the Taman Bay in the area of the village of Sennoy as a conditionally pristine background area. It is shown that in this area a certain part of $\mathrm{Ca}, \mathrm{S}, \mathrm{Fe}$ and $\mathrm{Pb}$ enters the sea with coastal runoff, but in the coastal zone some of these elements settle and accumulate in bottom sediments

c. The increase with the removal of the Sr, As and P content from the coastline suggests that their accumulation in the bottom sediments may be associated with biogenic processes

d. The group of lithophilic and siderophilic elements is characterized by the highest dispersion, and chalcophilic elements ( $\mathrm{S}, \mathrm{As}, \mathrm{Cd}, \mathrm{Cu}$ ) - by concentration (or its tendency).

\section{References}

1. Phillips DJH (1977) The use of siological indicator organisms to monitor trace metal pollution in marine and estuarine environments: A review. Envir Pollut 13(4): 281-317.

2. Giusti L (2001) Heavy metal contamination of brown seaweed and sediments from the UK coastline between the Wear river and the Tees river. Environ Int 26(4): 275-286.

3. Foster P (1976) Concentrations and concentration factors of heavy metals in brown algae. Environm Pollut 10(1): 45-53.

4. Morris AW, Bole AJ (1975) The accumulation of cadmium, copper, manganese and zinc by Fucus vesiculosus in the Bristol Channel Estuarine. Coast Marine Sci 3(2): 153-163.

5. Baldantoni D, Ligrone R, Alfani A (2009) Macro and trace-element concentrations in leaves and roots of Phragmites Australis in a volcanic lake in Southern Italy. Journal of Geochemical Exploration 101(2): 166174 .

6. Bonanno G (2011) Trace element accumulation and distribution in the organs of Phragmites Australis (common reed) and biomonitoring applications. Ecotoxicology and Environmental Safety 74(4): 10571064.

7. Bragato C, Schiavon M, Polese R, Ertani A, Pittarello M, et al. (2009) Seasonal variations of $\mathrm{Cu}, \mathrm{Zn}, \mathrm{Ni}$ and $\mathrm{Cr}$ concentration in Phragmites Australis (Cav.) Trin ex Steud in a constructed wetland of North Italy. Desalination 246(1-3): 35-44.

8. Guilizzoni P (1991) The role of heavy metals and toxic materials in the physiological ecology of submersed macrophytes. Aquatic Botany 41(13): $87-109$.

9. Barreiro R, Picado L, Real C (2002) Biomonitoring heavy metals in estuaries: a field comparison of two brown algae species inhabiting upper estuarine reaches. Environ Monit Assess 75(2): 121-134.

10. Caliceti M, Argese E, Sfriso A, Pavoni B (2002) Heavy metal contamination in the seaweeds of the Venice lagoon. Chemosphere 47(4): 443-454.

11. Haug A, Melson S, Omang S (1974) Estimation of heavy metal pollution in two norwegion fiord by analysis of the brown algae ascophyllum nodosum. Environ Pollut 7(3): 179-192.

12. Malea P, Haritonidis S, Kevrekidis T (1995) Metal content of some green and brown seaweeds from Antikyra Gulf (Greece). Hydrobiologia 310(1): 19-31.

13. Riget F, Johansen P, Asmund G (1995) Natural seasonal variation of cadmium, copper, lead and zinc in brown seaweeds (Fucus vesiculosus). Mar Pollut Bull 30(6): 409-413.

14. Izrael Yu A (1974) Global Observing System. Forecast and assessment of the environment. Fundamentals of Monitoring. Meteorology and Hydrology 7: 3-8.

15. Izrael Yu A (1979) Ecology and control of the state of the environment. L: Gidrometeoizdat, p. 376.

16. Izrael Yu A, Tsyban AV (2009) Anthropogenic ecology of the ocean. Moscow: Flint Science, p. 529.

17. Patin SA (1979) Impact of pollution on biological resources and productivity of the oceans. M: Pishepromizdat, p.325. 
18. Patin SA (1982) Pollution and biological resources of the oceans Butterworth Scientific, London, UK, p. 320.

19. Burdin KS (1985) Fundamentals of biological monitoring. Moscow State University, Moscow, p. 156.

20. Khristoforova NK (1989) Bioindication and monitoring of pollution of sea water with heavy metals. L: Science, p. 192.

21. Matishov GG (1991) Common causes of crisis phenomena in the ecosystems of the seas of Northern Europe. Ecological situation and protection of flora and fauna of the Barents Sea. Apatity, Russia, pp. 8-34.
22. Frontasyeva MV (2011) Neutron activation analysis for the life sciences. Physics of Elementary Particles and Atomic Nuclei 42(2): 332-378.

23. Vinogradov AP (1962) Average content of chemical elements in the chief types of igneous rocks of the crust of the earth. Geokhimiya 7(7): 641664.

24. Kamnev AN (1989) The structure and functions of the brown algae. MSU, p. 200.

For possible submissions Click below: 